\title{
Revegetating Russian Knapweed (Acroptilon repens) Infestations Using Morphologically Diverse Species and Seedbed Preparation
}

\author{
Jane M. Mangold, ${ }^{1}$ Clare L. Poulsen, ${ }^{2}$ and Michael F. Carpinelli ${ }^{3}$ \\ Authors are ${ }^{1}$ Rangeland Ecologist and; ${ }^{2}$ Rangeland Technician, Eastern Oregon Agricultural Research Center, United States Department of Agriculture- \\ Agricultural Research Service, Burns, OR 97720; and ${ }^{3}$ Rangeland Management Specialist, Grants Soil Survey Office, Grants, NM 87020.
}

\begin{abstract}
Highly degraded pastures and rangeland dominated by Russian knapweed (Acroptilon repens [L.] DC) are often devoid of desirable plants. Control efforts may be ephemeral because propagules of desirable species are not available to reoccupy niches made available by control procedures. Establishing desirable, competitive plants is essential for enduring management and restoration of Russian knapweed and other weed-infested plant communities. The objective of this study was to investigate the effectiveness of revegetating Russian knapweed-infested pastures with 3 nonnative, morphologically diverse species following 1 of 3 seedbed preparation treatments. In successive years, at 2 similar sites in southeastern Oregon, we sprayed Russian knapweed with glyphosate, then prepared the seedbed by burning, tilling, or leaving untreated. Following seedbed preparation, we seeded a perennial forb (alfalfa [Medicago sativa L.]), a bunchgrass (Siberian wheatgrass [Agropyron fragile \{Roth\} P. Candargy subsp. sibericum [Willd.\} Melderis]), and a sod-forming grass (pubescent wheatgrass [Elytrigia intermedia \{Host\} Nevski subsp. trichophora \{Link\} Tvzel]) in monocultures and 2- and 3-species mixtures. We measured Russian knapweed and seeded-species density 1 and 2 years following seeding. The forb-seeding treatment decreased reinvasion of Russia knapweed by $50 \%-60 \%$ at 1 site, but otherwise, seeding treatment had little influence on total seeded-species density or Russian knapweed density. Tilling generally resulted in a 35\%-40\% reduction in Russian knapweed density compared with the control and resulted in the highest establishment of seeded species. Variability in annual precipitation appeared to influence seeded-species establishment between the sites. Our results suggest shallow tilling $(10-15 \mathrm{~cm})$ followed by drill-seeding desirable forbs and grasses may provide the best results when revegetating Russian knapweed infestations. Follow-up management should include strategies to enhance desirable species production while minimizing Russian knapweed reinvasion.
\end{abstract}

\section{Resumen}

Los pastizales y praderas altamente degradadas, dominadas por "Russian knapweed" (Acroptilon repens [L.] DC), a menudo están desprovistas de plantas deseables. Los esfuerzos de control pueden ser efímeros, porque los propágulos de las plantas deseables pueden no estar disponibles para reocupar los nichos hechos disponibles por los procedimientos de control. El establecimiento de plantas deseables competitivas es esencial para el manejo duradero y la restauración de comunidades de plantas infestadas por "Russian knapweed" y otras malezas. El objetivo de este estudio fue investigar la efectividad de revegetar potreros infestados de "Russian knapweed" con 3 especies introducidas y morfológicamente diversas, sembradas después de 1 de 3 tratamientos de preparación de la cama de siembra. En años sucesivos, en 2 sitios similares en el sudeste de Oregon, asperjamos el "Russian knapweed" con glifosato, después preparamos la cama de siembra quemando, con labranza o dejándola sin tratar. Posterior a la preparación de la cama de siembra, sembramos una hierba perenne ("Alfalfa" [Medicago sativa L.]), un zacate amacollado ("Siberian wheatgrass" [Agropyron fragile \{Roth\} P. Candargy subsp. sibericum \{Willd.\} Melderis]) y un zacate formador de césped (pubescent wheatgrass [Elytrigia intermedia \{Host\} Nevski subsp. trichophora \{Link\} Tvzel]), las especies se sembraron en monocultivo y en mezclas de 2 y 3 especies. Medimos la densidad del "Russian knapweed" y de las especies sembradas 1 y 2 años después de la siembra. El tratamiento de siembra de la hierba disminuyó la reinvasión de "Russian knapweed" en 50\%-60\% en el sitio 1, pero por otra parte, el tratamiento de siembra tuvo poca influencia en la densidad total de las especies sembradas o del "Russian knapweed". Comparado con el control, la labranza generalmente ocasionó una reducción del "Russian knapweed" del orden de $35 \%-40 \%$ y resultó en el mayor establecimiento de las especies sembradas. La variabilidad de la precipitación anual pareció influir en el establecimiento de las especies introducidas entre sitios. Nuestros resultados sugieren que la labranza superficial $(10-15 \mathrm{~cm})$, seguida de la siembra mecánica de especies herbáceas y gramíneas deseables, puede dar los mejores resultados para revegetar las infestaciones de "Russian knapweed." El manejo complementario debe incluir estrategias para aumentar la producción de especies deseables mientras se minimiza la reinvasión del "Russian knapweed."

Key Words: invasive weeds, seedbed preparation, seedling establishment, weed control

The Eastern Oregon Agricultural Research Center is jointly funded by the US Dept of Agriculture-Agricultural Research Service and Oregon State Agricultural Experiment Station. Mention of a proprietary product does not constitute a guarantee or warranty of the product by USDA or the authors and does not imply its approval to the exclusion of other products. Correspondence: Jane M. Mangold, Eastern Oregon Agricultural Research Center, United States Department of Agriculture-Agricultural Research Service, 67826-A Highway 205, Burns, OR 97720. Email: jane.mangold@oregonstate.edu

Manuscript received 13 June 2006; manuscript accepted 17 March 2007. 


\section{INTRODUCTION}

Russian knapweed (Acroptilon repens [L.] DC) is a perennial, exotic, invasive forb declared noxious in 25 states and 4 provinces in the United States and Canada (Rice 2006). It is native to Eurasia, was accidentally introduced to North America in the late 1800s, and now infests over 500000 ha in the western United States (Whitson 1999). Russian knapweed spreads from adventitious root buds and can rapidly colonize an area, forming dense monocultures. It competes with desirable forage and exhibits allelopathic characteristics (Fletcher and Renney 1963). Russian knapweed frequently occurs in areas that have shallow water tables or extra water from irrigation (Whitson 1999).

The extensive root system of Russian knapweed makes it extremely difficult to control. Cultivation has been found to increase the rate of spread of Russian knapweed, and handpulling is not effective because the plant will rapidly resprout (Duncan et al. 2002). Biological control agents have been released on Russian knapweed, but they are established in small numbers and have not been effective to date (Duncan et al. 2002). Grazing with goats is receiving increasing attention and shows promise as a component of integrated management for Russian knapweed (Richman et al. 2006). The most common and effective method of control for Russian knapweed is through herbicide application. However, chemical control is costly, nontarget organisms may be harmed, groundwater contamination must be avoided, and treated areas may require retreatment as plants recur from vegetative reproduction and viable seeds in the seedbank (Benz et al. 1999). Furthermore, chemical treatment of Russian knapweed monocultures may result in bare ground (Benz et al. 1999).

Highly degraded pastures and rangeland dominated by Russian knapweed are often devoid of desirable plants. Control efforts may be ephemeral because propagules of desirable species are not available to reoccupy niches made available by control procedures (Sheley et al. 1996). Establishing competitive plants is essential for enduring control of Russian knapweed and other weed infestations and the restoration of desirable plant communities (Larson and McInnis 1989; Borman et al. 1991; Whitson 1999). Although seeding nonnative species is somewhat controversial, they can be easier to establish than native species and very competitive once established (Bottoms and Whitson 1998). Revegetating with nonnative, desirable species may be useful where rehabilitation of plant community function, enhanced wildlife and livestock forage, and invasion resistance are primary land-use objectives (Sheley and Carpinelli 2005).

Some evidence indicates that where desirable species are complementary in niche, plant communities with high species richness and diversity may resist invasion more than those with low species richness and diversity (Tilman 1997; Naeem et al. 2000; Dukes 2001). After 3 years, Carpinelli (2000) found that the establishment of the deeply rooted forb alfalfa (Medicago sativa L.), the bunchgrass crested wheatgrass (Agropyron cristatum [L.] Gaertn.), and the rhizomatous intermediate wheatgrass (Elytrigia intermedia [Host] Nevski) resisted invasion by spotted knapweed (Centaurea maculosa Lam.) best when all 3 species were growing together vs. any 1 species growing alone. After 7 years, a negative relationship remained between species richness and spotted knapweed biomass, but the crested wheatgrass and alfalfa mixture seemed to be more resistant to invasion than monocultures or other combinations (Sheley and Carpinelli 2005). Revegetating weed-infested plant communities with multiple species that occupy a range of niches may increase desirable species establishment and limit reinvasion by weeds.

The objective of this study was to investigate the effectiveness of revegetating Russian knapweed-infested pastures with 3 nonnative, morphologically diverse species following Russian knapweed chemical control and 1 of 3 seedbed preparation treatments (burning, tilling, untreated control). We hypothesized that seeding with a mix of morphologically diverse pasture species would increase seeded-species density and decrease Russian knapweed density more effectively than seeding individual species alone or seeding no species following an herbicide application and seedbed preparation. Because Bottoms and Whitson (1998) reported tilling alleviated allelopathic effects of Russian knapweed, we also hypothesized that seedling establishment would be greatest when the seedbed was tilled.

\section{MATERIALS AND METHODS}

The study was conducted at 2 sites in southeastern Oregon, located approximately $10 \mathrm{~km}$ east of Burns, Oregon. The sites (lat $43^{\circ} 35^{\prime} 05^{\prime \prime} \mathrm{N}$, long $118^{\circ} 57^{\prime} 24^{\prime \prime} \mathrm{W}$ ) were about $2 \mathrm{~km}$ apart at an elevation of $1240 \mathrm{~m}$. Average annual precipitation is $270 \mathrm{~mm}$ and temperatures range from $-1.2^{\circ} \mathrm{C}$ for an average low in January to $14.9^{\circ} \mathrm{C}$ for an average high in July. Soils at Site 1 are fine-loamy, mixed, superactive, frigid Vitritorrandic (Calcidic) Haploxerolls. Soils at Site 2 are fine-silty, mixed, superactive, frigid Sodic Haplocalcids. The sites were alfalfa hay pastures that had been dominated by Russian knapweed for at least the past 15 years (mean density $\approx 75 \mathrm{stems} \cdot \mathrm{m}^{2}$ at Site 1 and $\approx 57$ stems $\cdot \mathrm{m}^{2}$ at Site 2 ). Whitetop (Cardaria draba [L.] Desv.) and yellow sweetclover (Melilotus officinalis [L.] Lam.) were occasionally observed before application of any treatments. Weather data were collected from the National Oceanic and Atmospheric Association (NOAA) station at the Burns, Oregon, municipal airport located about $3 \mathrm{~km}$ from the study sites (Fig. 1).

The revegetation process consisted of 4 steps: 1) initial seedbed preparation with 1 of 3 methods; 2) chemical control of Russian knapweed; 3) second seedbed preparation with 1 of the same 3 methods as in initial treatment; and 4) seeding mixtures of 0 (unseeded control), 1, 2, or 3 desirable species. We tested 3 seedbed preparation methods including burning, tilling, and an untreated control. A 3-m-wide propane torch pulled behind an all-terrain vehicle (ATV) was used to apply the burning treatments. A Kubota tractor, with a 1.2-m-wide rototiller, tilling $10-15 \mathrm{~cm}$ deep, was used for the tilling treatments. Russian knapweed was controlled by spraying glyphosate (RoundUp UltraMax) at $7 \mathrm{~L} \cdot \mathrm{ha}^{-1}$ with an ATVmounted boomless sprayer. We seeded a forb (F; Ladak alfalfa), a bunchgrass (B; Vavilov Siberian wheatgrass [Agropyron fragile \{Roth\} P. Candargy subsp. sibericum \{Willd.\} Melderis]), and a sod-forming grass (S; Luna pubescent wheatgrass [Elytrigia intermedia \{Host\} Nevski subsp. tricho- 


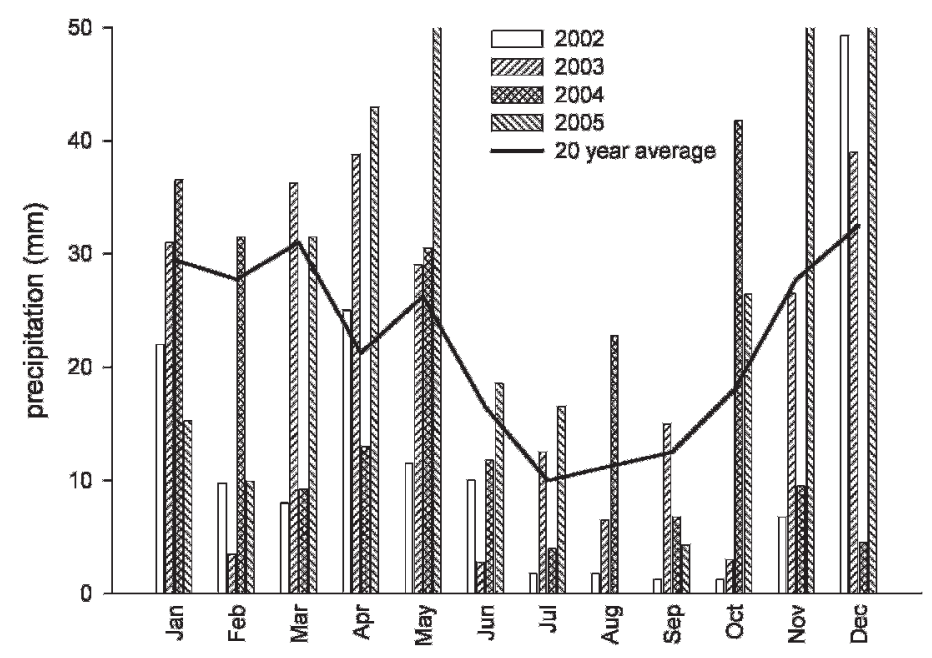

Figure 1. Monthly (2002-2004) and monthly average (1973-2003) precipitation in millimeters $(\mathrm{mm})$ at Burns, OR, municipal airport, located approximately $3 \mathrm{~km}$ from study sites.

phora $\{$ Link $\}$ Tvzel]) in 1-, 2-, and 3-species mixtures. Seeding rates for each species were based on recommended agronomic seeding rate for each species when sown in monoculture and varied according to the total number of species seeded. For 1species treatments, the forb was seeded at 462 seeds $\cdot \mathrm{m}^{-2}$ $\left(10 \mathrm{~kg} \cdot \mathrm{ha}^{-1}\right)$, the bunchgrass was seeded at $336 \mathrm{seeds} \cdot \mathrm{m}^{-2}$ $\left(9 \mathrm{~kg} \cdot \mathrm{ha}^{-1}\right)$, and the sod-forming grass was seeded at 434 seeds $\cdot \mathrm{m}^{-2}\left(25 \mathrm{~kg} \cdot \mathrm{ha}^{-1}\right)$. For 2 -species treatments seeding rates were one-half of 1-species seeding rates, and for 3-species treatments, seeding rates were one-third of 1-species seeding rates.

The application of treatments occurred during 2001 through 2002 for Site 1 and 2002 through 2003 for Site 2. Russian knapweed at Site 1 was sprayed at early bud stage (August) and postflowering stage (September) 2002. Site 2 was sprayed at similar phenological stages in 2003. Site 1 was burned and tilled in fall 2001 and fall 2002. Site 2 was burned and tilled in fall 2002 and fall 2003. Site 1 was seeded 12 November 2002, and Site 2 was seeded 17 November 2003.

Treatments were arranged in a strip-plot, randomized-block design. Seedbed preparation treatments were placed in strips, and seeding treatments were placed in strips running perpendicular to the seedbed preparation treatments. Seedbed preparation strips were $61.5 \mathrm{~m} \times 6 \mathrm{~m}$ with a $1.5-\mathrm{m}$ border between strips. Seeding treatment strips were $91.5 \mathrm{~m} \times 6 \mathrm{~m}$ with a $1.5-\mathrm{m}$ border between strips. The full factorial design was replicated 4 times and resulted in 76, $6 \mathrm{~m} \times 6 \mathrm{~m}$ plots per site $(3$ seedbed treatments $\times 8$ seeding treatments $\times 4$ replications).

Seeded species, Russian knapweed, and other species densities were sampled from 3 randomly placed $0.5-\mathrm{m}^{2}$ frames in each plot. For grasses and forbs, grass tillers (i.e., culms arising from a single crown) and stems (i.e., stems arising from a single crown) were counted, respectively. Sampling did not occur within $1 \mathrm{~m}$ of the edge of the plots to avoid border effects. Site 1 plots were sampled October 2003 and August 2004. Site 2 plots were sampled July 2004 and August 2005. Destructive sampling to estimate biomass was not performed because we wanted to avoid affecting young seedlings emerging from seeds or Russian knapweed regenerating vegetatively. The occurrence of species other than seeded species and Russian knapweed was minimal, so those data were not included in analysis.

Sites were analyzed separately. A split-plot-in-time analysis of variance (ANOVA) was used to determine the effects of seedbed preparation, seeding treatments, and year of sampling (hereafter referred to as seedbed, seeding, and year, respectively) on Russian knapweed and seeded-species densities (SAS Institute Inc 1990). Whole-plot effects were seedbed, seeding, and seedbed-by-seeding treatment interaction. Split-plot effects were year, year-by-seedbed interaction, year-by-seeding interaction, and year-by-seedbed-by-seeding interaction. Russian knapweed data were natural log-transformed, and bunchgrass, sod grass, and forb data were square root-transformed to meet the assumptions of normality and equality of variance. When a significant model $P$ value was calculated $(\alpha \leq 0.05)$, mean separations for significant main effects and interactions were achieved using Tukey's honest significant difference (HSD) (Milliken and Johnson 1984). Actual means are presented, but mean separations were performed on transformed data.

\section{RESULTS}

\section{Russian Knapweed}

Russian knapweed density was affected by the year-by-seedbed interaction $(P<0.01)$ at Site 1 (Table 1$)$. Burning increased Russian knapweed density by about 40\%, whereas tilling decreased Russian knapweed density by about 35\% compared with the control in Year 1 (Fig. 2A). Seedbed treatment had no effect in Year 2.

At Site 2, Russian knapweed density was influenced by the year-by-seedbed interaction $(P<0.01$, Table 1$)$. Seedbed treatment did not affect Russian knapweed density in Year 1 $\left(\approx 16.1\right.$ stems $\cdot \mathrm{m}^{-2}$, Fig. $\left.2 \mathrm{~B}\right)$. In Year 2 , however, tilling resulted in lower Russian knapweed density than either the burn treatment or the control. Density was higher in Year 2 than in Year 1 regardless of treatment. Russian knapweed was also influenced by the year-by-seeding treatment interaction $(P<0.01)$ at Site 2 (Table 1$)$. One year following treatment, all seeding treatments resulted in about 20 stems $\cdot \mathrm{m}^{-2}$ (Fig. 3). Most treatments resulted in a 4- to 5-fold increase in Russian knapweed density in Year 2 compared with Year 1. The only exception was the forb treatment. which remained similar to Year 1 at $41 \mathrm{stems} \cdot \mathrm{m}^{-2}$.

\section{Siberian Wheatgrass}

Siberian wheatgrass density was influenced by year and the seedbed-by-seeding interaction at Site $1 \quad(P<0.01$ and $P=0.03$, respectively, Table 1$)$. Siberian wheatgrass density was higher in Year 1 (4.3 tillers $\left.\cdot \mathrm{m}^{-2}\right)$ than in Year $2(1.6$ tillers $\cdot \mathrm{m}^{-2}$ ). Tilling generally resulted in the highest establishment of Siberian wheatgrass (Fig. 4). The highest densities occurred where tilling was combined with the sod-bunchgrass (7.6 tillers $\left.\cdot \mathrm{m}^{-2}\right)$ and bunchgrass-forb $\left(11.3\right.$ tillers $\left.\cdot \mathrm{m}^{-2}\right)$ seeding treatments. Control and burn treatments resulted in very low, and generally similar, Siberian wheatgrass densities, typically fewer than 2 tillers $\cdot \mathrm{m}^{-2}$. 
Table 1. ANOVA $P$ values for the influence of whole-plot and split-plot main effects and interactions on Russian knapweed, Siberian wheatgrass, pubescent wheatgrass, alfalfa, and total seeded-species density at Site 1 and Site 2. Russian knapweed densities were natural log-transformed, whereas Siberian wheatgrass, pubescent wheatgrass, alfalfa, and total seeded-species densities were square root-transformed to normalize data and equalize variance.

\begin{tabular}{|c|c|c|c|c|c|}
\hline Source & Russian knapweed & Siberian wheatgrass & Pubescent wheatgrass & Alfalfa $^{1}$ & Total seeded species \\
\hline \multicolumn{6}{|l|}{ Site 1} \\
\hline Seedbed treatment (SB) & $<0.0001$ & $<0.0001$ & $<0.0001$ & NA & $<0.0001$ \\
\hline Seeding treatment (S) & 0.1404 & 0.0280 & 0.0419 & NA & 0.3318 \\
\hline$S B \times S$ & 0.4627 & 0.0288 & 0.5643 & NA & 0.0787 \\
\hline Year & $<0.0001$ & $<0.0001$ & $<0.0001$ & NA & $<0.0001$ \\
\hline Year $\times$ SB & 0.0002 & 0.1231 & 0.0002 & NA & 0.0017 \\
\hline Year $\times S$ & 0.3109 & 0.9286 & 0.3536 & NA & 0.2001 \\
\hline Year $\times \mathrm{SB} \times \mathrm{S}$ & 0.4075 & 0.3836 & 0.5380 & NA & 0.5831 \\
\hline \multicolumn{6}{|l|}{ Site 2} \\
\hline Seedbed treatment (SB) & 0.0013 & $<0.0001$ & $<0.0001$ & 0.4435 & 0.1104 \\
\hline Seeding treatment (S) & 0.0232 & $<0.0001$ & $<0.0001$ & 0.1547 & 0.0007 \\
\hline $\mathrm{SB} \times \mathrm{S}$ & 0.7458 & 0.1183 & 0.0818 & 0.2518 & 0.1490 \\
\hline Year & $<0.0001$ & $<0.0001$ & $<0.0001$ & $<0.0001$ & $<0.0001$ \\
\hline Year $\times$ SB & 0.0144 & 0.2833 & 0.1122 & 0.4676 & 0.1107 \\
\hline Year $\times S$ & 0.0010 & $<0.0001$ & $<0.0001$ & 0.3815 & 0.8347 \\
\hline Year $\times S B \times S$ & 0.9735 & 0.2383 & 0.4830 & 0.7045 & 0.6361 \\
\hline
\end{tabular}

${ }^{1} \mathrm{NA}$ indicates not applicable.

The main effect of seedbed treatment $(P<0.01)$ and the year-by-seeding interaction $(P<0.01)$ influenced Siberian wheatgrass density at Site 2 (Table 1). Similar to Site 1, tilling at Site 2 resulted in the highest Siberian wheatgrass density (42.8 tillers $\cdot \mathrm{m}^{-2}$ ) compared with burning (29.6 tillers $\cdot \mathrm{m}^{-2}$ ) and the control $\left(25.8\right.$ tillers $\left.\cdot \mathrm{m}^{-2}\right)$. At Site 2, Siberian wheatgrass densities were higher in Year 2 than in Year 1 (Fig. 5). The highest Siberian wheatgrass densities occurred in the bunchgrass (123 tillers $\cdot \mathrm{m}^{-2}$ ) and sod-bunchgrass (82.0 tillers $\cdot \mathrm{m}^{-2}$ ) seeding treatments. These densities were about 40 times higher than densities 1 year following seeding $(\approx 2.3$ tillers $\cdot \mathrm{m}^{-2}$ ). In Year 2, the bunchgrass-forb and sodbunchgrass-forb treatments resulted in Siberian wheatgrass densities of 25.5 tillers $\cdot \mathrm{m}^{-2}$ and 21.9 tillers $\cdot \mathrm{m}^{-2}$, respectively, about 10 times higher than in these same treatments in Year 1.

\section{Pubescent Wheatgrass}

Pubescent wheatgrass density at Site 1 was influenced by seeding treatment $(P=0.04)$ and the year-by-seedbed interaction $(P<0.01$, Table 1$)$. The highest density resulted from the sod treatment at 6.6 tillers $\cdot \mathrm{m}^{-2}$. This was higher than the sodbunchgrass (3.7 tillers $\cdot \mathrm{m}^{-2}$ ) and sod-bunchgrass-forb (2.9 tillers $\left.\cdot \mathrm{m}^{-2}\right)$ treatments. The sod-forb $\left(4.6\right.$ tillers $\left.\cdot \mathrm{m}^{-2}\right)$ treatment was intermediate between the sod and other 2 seeding treatments. As with Siberian wheatgrass density, pubescent wheatgrass density was highest in the tilling treatment at 17.4 tillers $\cdot \mathrm{m}^{-2}$ in Year 1 (Fig. 6). Density in the till treatment decreased to 3.6 tillers $\cdot \mathrm{m}^{-2}$ in Year 2 but was higher than either the control or burn treatment at that time.

At Site 2, the main effect of seedbed treatment $(P<0.01)$ and the year-by-seeding interaction influenced pubescent wheatgrass density $(P<0.01$, Table 1$)$. Similar to Site 1 , tilling resulted in higher establishment of pubescent wheatgrass than the burn treatment $\left(36.8\right.$ tillers $\cdot \mathrm{m}^{-2}$ vs. 14.1 tillers $\left.\cdot \mathrm{m}^{-2}\right)$ but was similar to the control (31.1 tillers $\left.\cdot \mathrm{m}^{-2}\right)$. Pubescent wheatgrass density was higher 2 years following treatment $\left(\approx 51\right.$ tillers $\left.\cdot \mathrm{m}^{-2}\right)$ compared with 1 year following treatment $\left(\approx 4\right.$ tillers $\left.\cdot \mathrm{m}^{-2}\right)$, regardless of seeding treatment (Fig. 7). Pubescent wheatgrass density was highest in the sod-seeding treatment (122 tillers $\cdot \mathrm{m}^{-2}$ ). The sod-bunchgrass, sod-forb, and sod-bunchgrass-forb treatments during Year 2 were all similar at $37.0,23.5$, and 20.5 tillers $\cdot \mathrm{m}^{-2}$, respectively.

\section{Alfalfa}

Alfalfa did not establish at Site 1 and was therefore not analyzed. At Site 2, only the main effect of year influenced alfalfa density $(P<0.01$, Table 1$)$. Similar to density of other seeded species at Site 2, forb density increased over time from $13.0 \mathrm{stems} \cdot \mathrm{m}^{-2}$ to $176 \mathrm{stems} \cdot \mathrm{m}^{-2}$.

\section{Total Seeded Species}

Year and seedbed interacted to influence total seeded-species density at Site $1(P<0.01$, Table 1$)$. Similar to results for individual species, tilling resulted in the highest seeded-species density, followed by burning and the control in Year 1 and Year 2 (Fig. 8). Across treatments total seeded-species density decreased from Year 1 to Year 2 by about $75 \%$.

At Site 2, the main effects of year and seeding treatment influenced total seeded-species density $(P<0.01$, Table 1$)$. Total seeded-species density was 11.5 stems and tillers $\cdot \mathrm{m}^{-2}$ in Year 1 and increased to 174 stems and tillers $\cdot \mathrm{m}^{-2}$ in Year 2. Generally, the seeding treatments resulted in similar total seeded-species density $\left(\approx 97\right.$ stems and tillers $\left.\cdot \mathrm{m}^{-2}\right)$, except for the bunchgrass treatment $\left(67.1\right.$ stems and tillers $\left.\cdot \mathrm{m}^{-2}\right)$, which was lower than the forb, sod-forb, and bunchgrass-forb seeding treatments (Fig. 9). Alfalfa comprised the majority of total seeded-species density where alfalfa was seeded in a 2- or 3-species mix. 

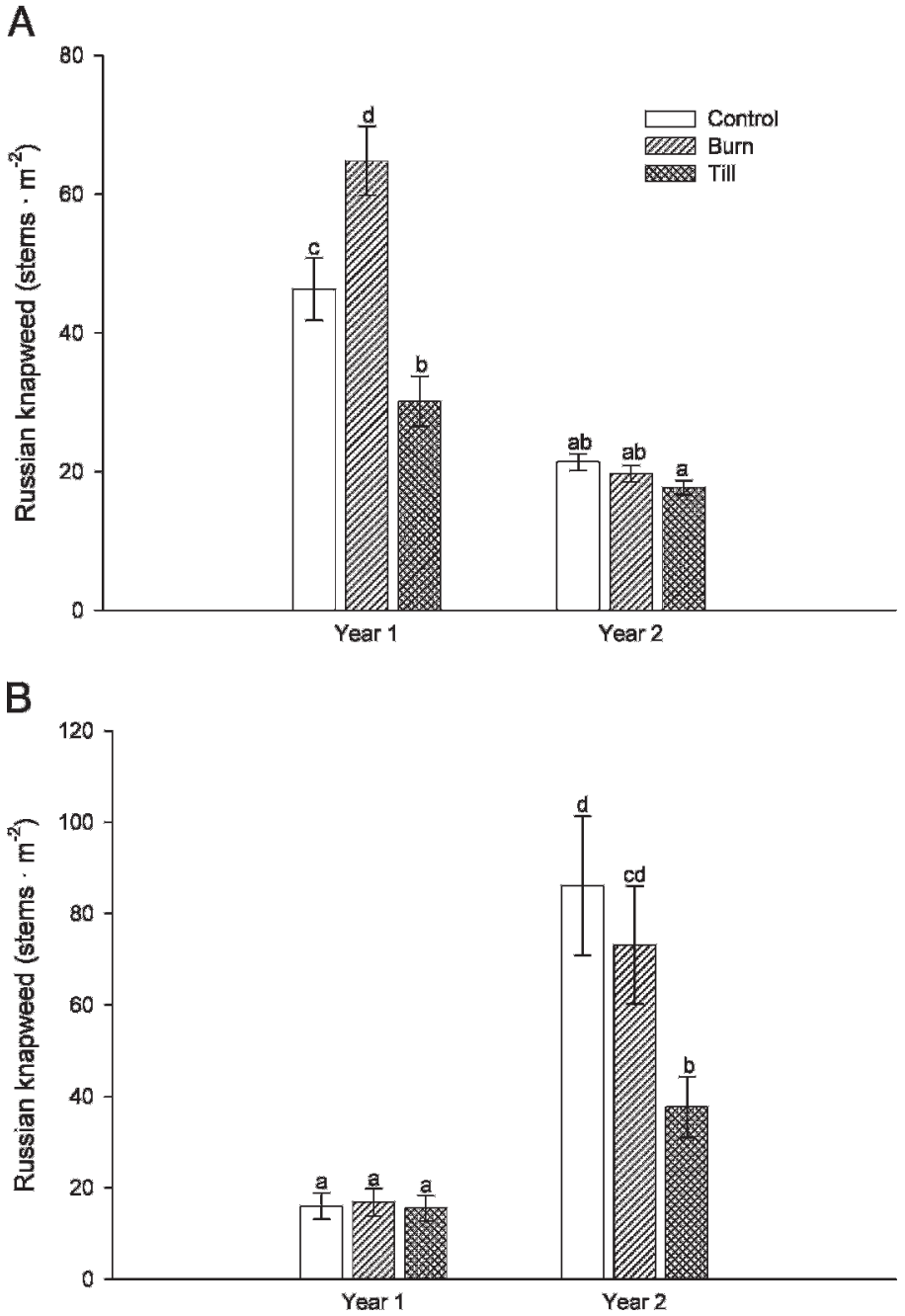

Figure 2. Year-by-seedbed preparation effect on mean Russian knapweed density at $\mathbf{A}$, Site 1 , and $\mathbf{B}$, Site 2. Letters separate means that are significantly different. Error bars represent $\pm 1 \mathrm{SE}$.

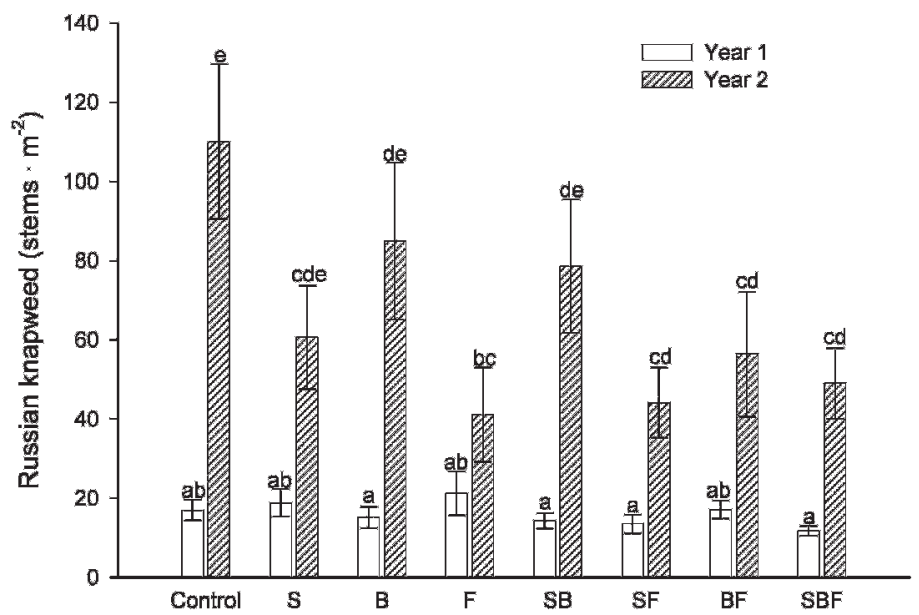

Figure 3. Year-by-seeding effect on mean Russian knapweed density at Site 2. Letters separate means that are significantly different. Error bars represent \pm 1 SE. S indicates sod; $B$, bunchgrass, and F, forb.

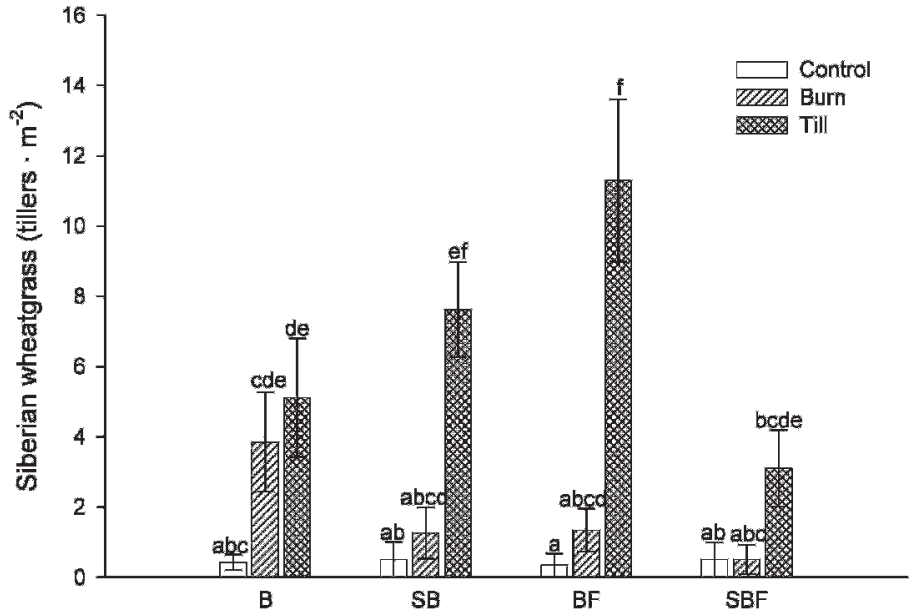

Figure 4. Seedbed preparation-by-seeding effect on mean Siberian wheatgrass density at Site 1. Letters separate means that are significantly different. Error bars represent \pm 1 SE. S indicates sod; B, bunchgrass; and F, forb.

\section{DISCUSSION}

The objective of this study was to investigate the effectiveness of revegetating Russian knapweed-infested pastures with 3 nonnative, morphologically different species following seedbed preparation and Russian knapweed control. Similar to previous studies (Carpinelli 2000; Sheley and Carpinelli 2005), we hypothesized that seeding a morphologically diverse stand of pasture species would increase seeded-species density and decrease Russian knapweed density more effectively than seeding individual species alone or seeding no species following an herbicide application and seedbed preparation. We found that seeding a forb, bunchgrass, sod-grass species, or mixture of the 3 did not have a consistent influence on Russian knapweed across sites and years. Both sites were historically dryland alfalfa fields and considered highly productive by the landowners. In productive areas with high resource availability, plant community dynamics may be influenced more by

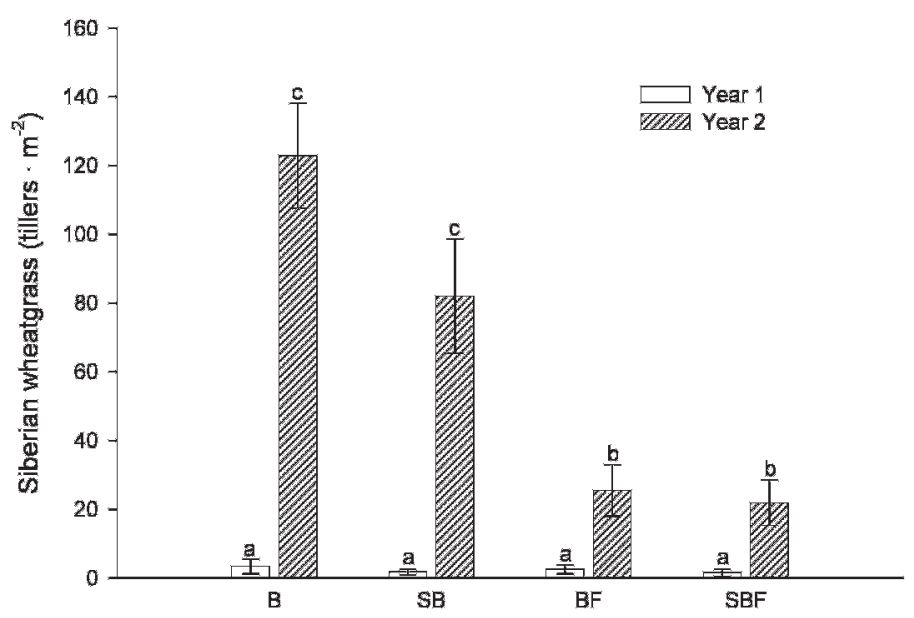

Figure 5. Year-by-seeding effect on mean Siberian wheatgrass density at Site 2. Letters separate means that are significantly different. Error bars represent \pm 1 SE. S indicates sod; B, bunchgrass; and F, forb. 


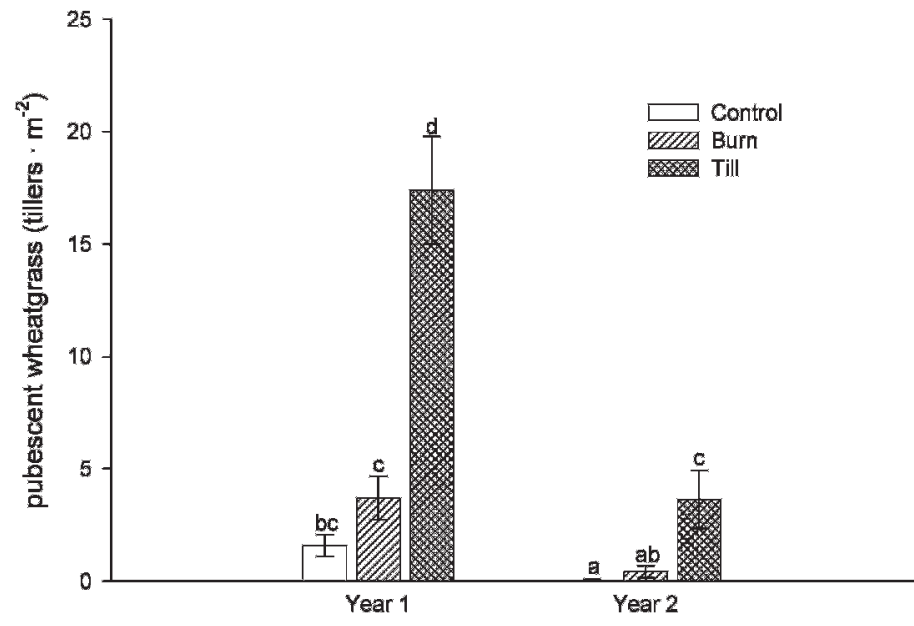

Figure 6. Year-by-seedbed preparation effect on mean pubescent wheatgrass density at Site 1. Letters separate means that are significantly different. Error bars represent \pm 1 SE.

ecological processes other than competition, such as seed production and dispersal and relative growth rate (Tilman 1982), thus weakening the positive correlation between species richness and invasion resistance. Establishing a species-rich plant community for invasion resistance may, therefore, be less important on highly productive sites (Sheley and Carpinelli 2005). Instead, temporarily controlling Russian knapweed to provide a window of opportunity for fast-growing desirable species to establish may be more important.

We found that the forb-seeding treatment or seeding treatments that contained the forb limited Russian knapweed reinvasion at Site 2 compared with the control, bunchgrass, sod grass, and sod-bunchgrass seeding treatments. Because alfalfa and Russian knapweed are morphologically similar, we believe these 2 species may have been more comparable in niche occupation than Russian knapweed was with the grasses. Competition may be more intense between functionally similar species (Lavorel et al. 1999), and when alfalfa establishment was high, as was the case at Site 2, Russian knapweed did not

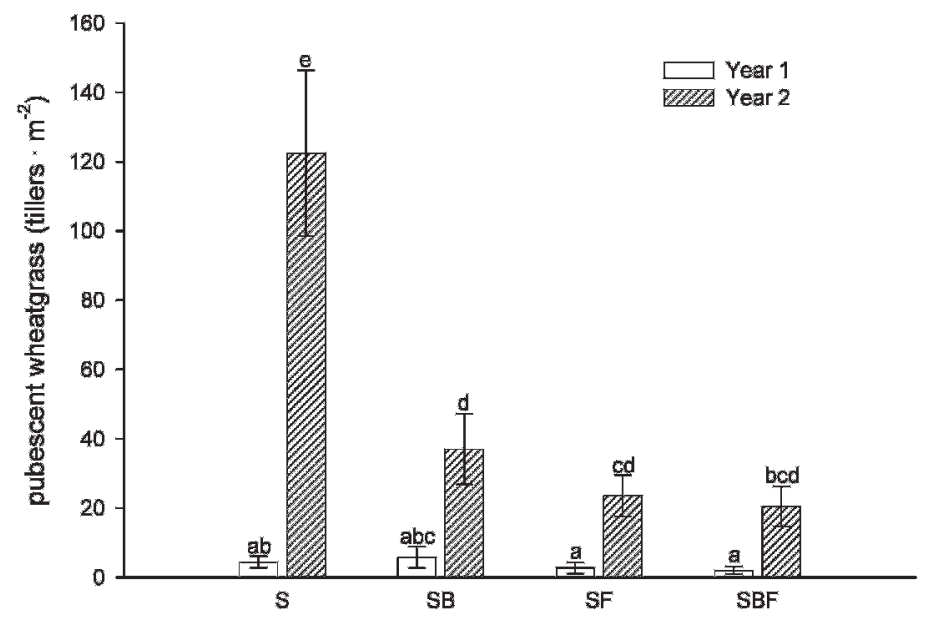

Figure 7. Year-by-seeding effect on mean pubescent wheatgrass density at Site 2 . Letters separate means that are significantly different. Error bars represent $\pm 1 \mathrm{SE}$.

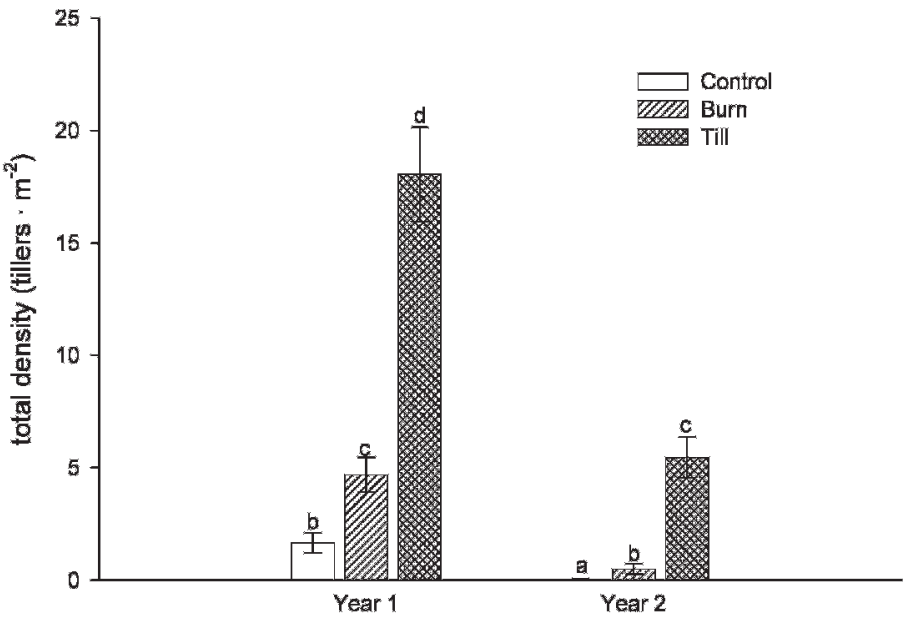

Figure 8. Year-by-seedbed preparation effect on mean density of seeded species at Site 1. Letters separate means that are significantly different. Error bars represent $\pm 1 \mathrm{SE}$.

reestablish as well as in other treatments. Pokorny et al. (2005) found recruitment of the invasive forb spotted knapweed was highest when all forbs were removed from a diverse, native plant community. They speculated that removal of a functional group that was morphologically similar to spotted knapweed may have opened complementary niches that allowed greater resource acquisition for spotted knapweed. In our case, it appeared that reinvasion by Russian knapweed may be limited when plots are dominated by a morphologically similar species.

Seedbed treatment influenced desirable species establishment and Russian knapweed control. Tilling generally increased establishment of seeded species and decreased Russian knapweed density. This is consistent with our hypothesis that seedling establishment would be best where the seedbed was prepared through tilling. Even though cultivation has been found to increase the rate of spread of Russian knapweed (Duncan et al. 2002), the tilling employed in this study may have provided enough short-term control of Russian knapweed, alleviated some of its allelopathic effects (Bottoms and

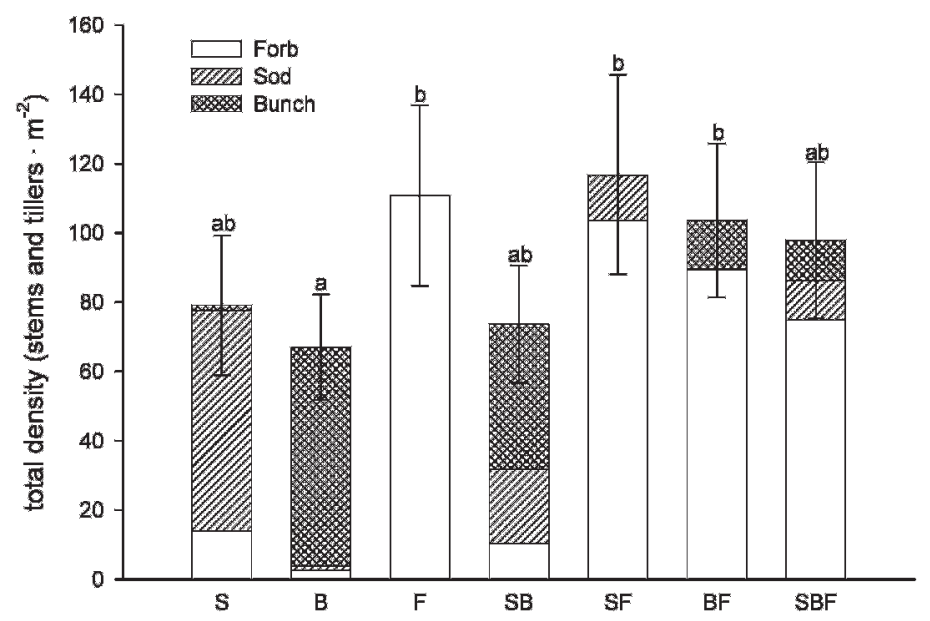

Figure 9. Seeding effect on mean density of seeded species at Site 2. Letters separate means that are significantly different. Error bars represent \pm 1 SE. S indicates sod; B, bunchgrass; and F, forb. 
Whitson 1998), and opened up temporary safe sites for establishment of desirable species. Similar to findings by Bottoms and Whitson (1998), burning did not appear to enhance establishment of desirable species nor offer any Russian knapweed control. Burning led to an increase in Russian knapweed in the first year at Site 1.

Russian knapweed density varied throughout the 3 years of the study and between the 2 sites, suggesting that temporal and spatial population variability in response to abiotic and biotic factors plays a significant role when assessing the effectiveness of any weed management activity. Weed density is assumed to be unpredictable and chaotic (Radosevich et al. 1997), and other studies have found weed populations to vary through time, even when no treatments were applied (Selleck et al. 1962; Lacey and Sheley 1996; Sheley et al. 2001; Seastedt et al. 2003). Our study suggests that additional control of Russian knapweed following seeding of desirable species may be necessary, such as biological control, prescription grazing, or spot-spraying a selective herbicide in late fall to limit Russian knapweed impacts on desirable species. Repeated monitoring is needed to properly evaluate the success or failure of management strategies and adjust as necessary (Johnson 1999).

Annual variability in precipitation may have been partly responsible for differences in seeded-species establishment between sites, especially alfalfa. At Site 1, densities of seeded species were higher 1 year following treatment (2003) than 2 years following treatment (2004). Precipitation during early spring following seeding (March-May 2003) was above average (Fig. 1), followed by a below-average precipitation in summer (June-August 2003). We speculate that alfalfa may have initially germinated and emerged with adequate moisture in early spring (March-April) but did not survive until the following year because of inadequate soil water recharge due to a drier-than-average winter (November 2002-February 2003) and the droughty conditions later in the summer. At Site 2, where alfalfa and the grasses established relatively well, precipitation was above normal the winter following seeding (November 2003-February 2004) and the first summer of growth (May-August 2004). The fate of seeds and seedlings in a semiarid environment is largely dependent on whether or not the seeds germinate during a wet period and how long water is available to the seedlings in the subsequent dry period (Frasier and Lopez 1990).

\section{MANAGEMENT IMPLICATIONS}

Revegetating Russian knapweed-infested pastures requires some control of the weed while preparing a seedbed conducive to establishment of fast-growing desirable species. Based on our results, we recommend shallow tilling $(10-15 \mathrm{~cm})$ and drillseeding of desirable forbs and grasses appropriate for the site. Managers should be cognizant of the amount and timing of precipitation events leading up to and following seeding because it may influence the outcome of revegetation. If possible, supplemental watering should be considered during droughty periods. Follow-up management should include strategies to enhance desirable species production while minimizing Russian knapweed reinvasion, such as biological control and grazing with goats at the appropriate time of year to minimize impact to desirable species.

\section{ACKNOWLEDGMENTS}

The authors wish to thank Allan Braymen and Steve Rickman, the cooperating landowners who provided study sites; Tony Svejcar for initial development of the study; Kirk Davies, Kim Reever Morghan, and Roger Sheley, who provided reviews of an earlier version of this manuscript; and anonymous reviewers.

\section{LITERATURE CITED}

Benz, L. J., K. G. Beck, T. D. Whitson, and D. W. Koch. 1999. Reclaiming Russian knapweed infested rangeland. Journal of Range Management 52:351-356.

Borman, M. M., W. C. Krueger, and D. E. Johnson. 1991. Effects of established perennial grasses on yields of associated annual weeds. Journal of Range Management 44:318-326.

Bottoms, R. M., AND T. D. Whitson. 1998. A systems approach for the management of Russian knapweed (Centaurea repens). Weed Technology 12:363-366.

Carpinelul, M. F. 2000. Designing weed-resistant plant communities by maximizing niche occupation and resource capture [dissertation]. Bozeman, MT: Montana State University. $131 \mathrm{p}$

DUKES, J. S. 2001. Biodiversity and invasibility in grassland microcosms. Oecologia 126:563-568.

Duncan, C., J. Story, and R. Sheley. 2002. Montana knapweeds: identification, biology, and management. Bozeman, MT: Montana State University Extension Bulletin 2C0311. $15 \mathrm{p}$.

Fletcher, R. A., and A. J. Renney. 1963. A growth inhibitor found in Centaurea spp. Canadian Journal of Plant Science 43:475-481.

Frasier, G. W., AND F. Lopez. 1990. Optimizing wet-dry precipitation probabilities for improving plant establishment. In: Proceedings of the Irrigation Conference Watershed Planning and Analysis in Action Symposium; 9-11 July 1990; Durango, CO. Durango, CO: American Society of Civil Engineers. p. 295-404.

JoHnson, D. E. 1999. Surveying, mapping, and monitoring noxious weeds on rangelands. In: R. L. Sheley and J. K. Petroff [EDS.]. Biology and management of noxious rangeland weeds. Corvallis, OR: Oregon State University Press. $p$. 19-35.

LACEy, J. R., and R. L. Sheley. 1996. Leafy spurge and grass response to picloram and intensive grazing. Journal of Range Management 49:311-314.

LARSON, L. L., AND M. L. McInNIS. 1989. Impact of grass seedlings on establishment and density of diffuse knapweed and yellow starthistle. Northwest Science 63:162-166.

Lavorel, S., A. H. Prieur-Richard, and K. Grigulis. 1999. Invasibility and diversity of plant communities: from patterns to processes. Diversity and Distributions 5:41-49.

Milliken, G. A., And D. E. Johnson. 1984. Analysis of messy data, volume 1: designed experiments. New York, NY: Chapman and Hall. 473 p.

Naeem, S., J. M. H. Knops, D. Tilman, K. M. Howe, T. Kennedy, and S. Gale. 2000. Plant diversity increases resistance to invasion in absence of covarying extrinsic factors. Oikos 91:97-108.

Pokorny, M. L., R. L. Sheley, C. A. Zabinski, R. E. Engel, T. J. Svejcar, and J. J. Bonkowski. 2005. Plant functional group diversity as a mechanism for invasion resistance. Restoration Ecology 13:448-459

Radosevich, S., J. Holt, and C. Ghersa. 1997. Weed ecology. New York, NY: John Wiley \& Sons Inc. 589 p.

RICE, P. M. 2006. INVADERS Database System. Available at: http://invader.dbs. umt.edu. Accessed 30 March 2006.

Richman, L., L. Larson, and M. Borman. 2006. Use of goats in Russian knapweed management. In: Proceedings of the Society for Range Management 59th Annual Meeting and Tradeshow. 12-17 February 2006; Vancouver, British 
Columbia, Canada. Wheat Ridge, C0: Society for Range Management. p. 198-199.

SAS Institute. 1990. SAS/STAT user's guide. Version 6. Volume 2. 4th ed. Cary, NC: SAS Institute. $1027 \mathrm{p}$.

SeAstedt, T. R., N. Gregory, and D. Buckner. 2003. Effect of biocontrol insects on diffuse knapweed (Centaurea diffusa) in a Colorado grassland. Weed Science 51:237-245.

Selleck, G. W., R. T. Coupland, and C. Frankton. 1962. Leafy spurge in Saskatchewan. Ecological Monographs 32:1-29.

Sheley, R. L., and M. F. Carpinelli. 2005. Creating weed-resistant plant communities using niche-differentiated nonnative species. Rangeland Ecology and Management 58:480-488.
Sheley, R. L., J. S. Jacobs, and D. E. Lucas. 2001. Revegetating spotted knapweed infested rangeland in a single entry. Journal of Range Management 54:144-151.

Sheley, R. L., T. J. Svejcar, and B. D. Maxwell. 1996. A theoretical framework for developing successional weed management strategies on rangeland. Weed Technology 10:712-720.

TıLmAn, D. 1997. Community invasibility, recruitment limitation, and grassland biodiversity. Ecology 78:81-92.

TiLman, D. 1982. Resource competition and community structure. Princeton, NJ: Princeton University Press. 298 p.

Whitson, T. D. 1999. Russian knapweed. In: R. L. Sheley and J. K. Petroff [eds.]. Biology and management of noxious rangeland weeds. Corvallis, OR: Oregon State University Press. p. 315-322. 